\title{
Años de aprendizaje de Riobaldo: el Gran Sertón
}

Fecha de recepción: 10/8/2020. Fecha de aceptación: 30/3/2021.

\section{Resumen}

El artículo busca identificar en Gran Sertón: Veredas de Guimarães Rosa algunos elementos de la novela de aprendizaje. Se observa que el relato utiliza un jagunço, bandolero del interior profundo brasileño como héroe que vivirá sus años de formación en una banda de criminales que asolan la región. El narrador-personaje concentra en sí una serie de características arcaicas, modernas, locales y universales que representan a nivel de la voz del relato la naturaleza contradictoria de la vida social brasileña, producto de su pasado colonial y su presente de nación subdesarrollada. El personaje protagonista tiene una actitud ambigua con respecto a la sociedad en la que vive. Cuando joven, rechaza los valores urbanos en nombre de una ética rural que en su caso incluye los códigos bandoleros. Cuando viejo, rescata algunos valores de la ciudad como la educación formal, pero sin adherir efusivamente a los mismos. El relato puede ser visto como un tipo particular de novela de aprendizaje que figura una vida social con profundas contradicciones como la brasileña.

Palabras clave: novela de aprendizaje; literatura brasileña; realismo.

Riobaldo's apprenticeship years: the Grande Sertão

\begin{abstract}
The paper seeks to identify in Gran Sertón: Veredas of Guimarães Rosa some elements of the Bildungsroman. The narration uses a cowboy from the Brazilian deep interior as a hero who will live through his training in a band of criminals
\end{abstract}


who lives in his region. The narrator concentrates in itself a series of archaic, modern, local and universal characteristics that represent the level of the voice of the report, the contradictory nature of Brazilian social life, originated in its colonial past and its present of underdeveloped nation. The main character has an ambiguous attitude with respect to the society in which he lives. When young, he rejects urban values in the name of a rural ethic that in his case includes bandit codes. When the old rescues some values of the city as the formal education but without effusive adherence to the same. The report could be seen as a particular type of learning novel that depicts a social life with profound contradictions like the Brazilian one.

Keywords: Bildungsroman; Brazilian Literature; realism.

Ah, vai vir um tempo, em que não se usa mais matar gente.... Rosa G. (1985, p.25)

\section{Introducción}

Pretendemos en este trabajo discutir la idea de que Gran Sertón: Veredas tiene algunos elementos de novela de aprendizaje cuyo modelo es Años de aprendizaje de Wilhelm Meister de Goethe. Primeramente, presentaremos una pequeña reseña de la novela de João Guimarães Rosa seguida de una breve reflexión sobre el concepto de novela de aprendizaje, para después, a través de tres preguntas, desarrollar este estudio.

\section{Breve reseña}

Gran Sertón: Veredas ocupa un lugar central en la producción literaria brasileña. La novela fue publicada en 1956. Su método de composición vanguardista mezcla la simple anotación de historias populares recolectadas por el autor en sus expediciones y aventuras por el Sertón mineiro, creaciones poéticas de vanguardia y formas literarias medievales y renacentistas como la novela de caballería y picaresca, que lo convirtieron en un texto fundamental de las letras brasileñas modernas. La obra está ambientada espacialmente en el Sertón (en portugués sertão, proveniente de desertão, "desierto grande"; plural: sertões) que es una vasta región geográfica semiárida que abarca el norte del Estado de Minas y todo el interior del Nordeste Brasileño. Es un desierto interrumpido de vez en cuando por veredas, lugares por donde pasan pequeños ríos, con un microclima más húmedo y lleno de vegetación. Sus habitantes se denominan sertanejos y a mediados del siglo XX todavía era una región predominantemente rural, ganadera muy atrasada, controlada por grandes terratenientes (fazendeiros), el Estado oligárquico está prácticamente ausente. La ley la ejerce el más fuerte, y la seguridad la garantizan grupos violentos llamados jagunços, paramilitares que dan protección a líderes políticos y a dueños de tierras. El narrador de la historia 
y personaje principal es Riobaldo, un ex-jagunço ahora devenido terrateniente, ya que heredó las tierras de su padrino. Riobaldo cuenta en un relato extenso (seiscientas páginas) sus aventuras por el sertón, a un oyente más letrado que él, denominado Doctor, que viene del lejano mundo de la ciudad, y que solo conocemos por referencias del narrador. El relato en primera persona cuenta cómo se transformó en bandolero, desde que voluntariamente sale de las tierras de su padrino hasta que se convierte en el jefe de la banda.

\section{Una novela de aprendizaje}

En una entrevista que el crítico Gunter Lorenz (1995) le hizo a Guimarães Rosa en los años 60 lo definió como el “Wilhelm Meister del Sertón”, debido principalmente a su actitud curiosa y aventurera y a que voluntariamente había salido a conocer el sertão mineiro para posteriormente convertirse en escritor. Apenas publicada, los críticos la relacionaron a la novela de aprendizaje o formación. Davi Arrigucci (1994) afirma que Wilhelm y Riobaldo tienen los mismos trayectos vitales: salida de la casa de los padres, aventuras y experiencias y reconciliación final con la realidad, al asumir el destino paterno. Para Arrigucci, la novela de aprendizaje es uno de los elementos compositivos fundamentales de Gran Sertón: Veredas. Entre las varias formas narrativas usadas por Guimarães Rosa, que incluyen la novela de aventuras, la novela caballeresca y la novela de vanguardia, encontramos trazos de la novela de aprendizaje, vinculados, por ejemplo, a la voluntad individual del protagonista-narrador de autoformarse en un mundo humano adverso.

\section{Breve reflexión sobre el género novela de aprendizaje}

La discusión sobre el estatus y las características del Bildungsroman o novela de educación o aprendizaje comienzan en el ámbito cultural alemán y llegan hasta nuestros días. La denominación Bildungsroman parece referirse a una producción literaria histórica y culturalmente determinada: el clasicismo alemán y el pensamiento ilustrado de finales del siglo XVII. Por otro lado, el término novela de formación se refiere a un ensayo o tratado filosófico sobre la educación y el de novela de aprendizaje (o de educación), que adoptaremos aquí, se refiere a una producción ficcional en la que su protagonista es un joven héroe que tiene que aprender el difícil arte de convertirse en adulto en una sociedad dinámica en la que el futuro aún no está escrito (cabe resaltar que los tres términos se han usado indistintamente). Franco Moretti (1987, p.5) en su excelente estudio sobre la novela de formación afirma que, en líneas generales, este género ofrece una inédita aproximación entre "mundo" y "subjetividad", pues la "formación" del protagonista, sus experiencias, sus viajes, sus conquistas y desilusiones al mismo tiempo reflejan y se oponen a su contexto histórico. Autonomía individual e integración social son las dos caras de un mismo trayecto. Estas formas novelescas son "hijas" de la Modernidad. 
Lukács parte de Hegel y Dilthey para elaborar su concepto de novela de aprendizaje (cf. Koval, 2015). Tiene dos variaciones. La primera, que aparece en Teoría de la Novela y es más optimista, ve al final del proceso de formación una reconciliación posible entre el individuo y la sociedad. En esta primera lectura, intenta establecer un punto medio entre las concepciones de Hegel y Dilthey y entiende la novela de Goethe como la puesta en escena de un acercamiento enriquecedor entre el individuo y la sociedad. Este concepto de reconciliación es posible para el joven Lukács ya que la novela de educación, como la llama, es la expresión de un humanismo idealista utópico, producto de una burguesía revolucionaria, que tiene esperanza en la naciente sociedad capitalista, contra la decadente aristocracia. En la segunda lectura, que podemos encontrar en un ensayo de 1968, Goethe y su época, el pensador húngaro va a cambiar su punto de vista y va a hacer hincapié en el "carácter irresoluble de las contradicciones" entre individuo y sociedad en el marco de la sociedad capitalista burguesa. Los héroes sí se dejan instruir voluntariamente por la realidad, sin embargo, la posibilidad de una reconciliación depende de la destrucción de la desigualdad de clases. En esta segunda versión Lukács retira la posibilidad de reconciliación.

Para la escuela de Frankfurt, la crisis existencial del hombre moderno hace imposible la persistencia de un género como la novela de aprendizaje, debido a la anulación del individuo en la sociedad administrada (cf. Adorno, 2003). W. Benjamin, en consonancia con Adorno, en un texto de 1930, Krisis des Romans. Zu Döblins, Berlin Alexanderplatz' (1972) y más tarde en sus estudios sobre Kafka (1985) describe el movimiento de los personajes kafkianos como procedimientos de alguien que se encuentra perdido en un mundo que no ofrece pistas claras del camino a seguir. Es una novela antiformativa.

En nuestro programa de análisis que incluye tres preguntas, buscaremos la presencia de algunos elementos de la novela de aprendizaje en Gran Sertón:Veredas, a saber:

a) ¿Qué características tiene el joven héroe de la novela y cómo encara su trayecto hacia la adultez?

b) ¿Qué papel juega la naturaleza en este trayecto? ¿Cómo interviene en el proceso formativo del héroe Riobaldo?

c) ¿Cómo se da la integración social del héroe?

\section{Características del héroe de la novela}

Si pensamos en Los Años de Aprendizaje de Wilhelm Meister como formato clásico de la novela de aprendizaje, tenemos en Gran Sertón: Veredas las siguientes características salientes: a) la evolución de un personaje, desde su niñez hasta su madurez; b) el relato tiene una finalidad propedéutica, al mismo tiempo contra-ejemplar (modelo a rechazar, el bandido) y ejemplar (modelo a seguir, el paladín, el justiciero) con una fuerte presencia de la voz autoral construyendo 
un narrador complejo en primera persona y c) su biografía corre paralela a un período de la historia de Brasil que, a pesar de que no es claramente identificada, corresponde al inicio del periodo republicano, caracterizado por el mantenimiento de formas arcaicas de producción en el campo, herencia del pasado colonial portugués, por una muy débil presencia del Estado, una incorporación de los territorios tradicionales al sistema del mercado mundial como áreas de producción ganadera en gran escala.

Riobaldo sale al mundo y será un jagunço, villano, bandido y marginal, justiciero, defensor de ciertas causas sociales y también un hombre enamorado, que finalmente terminará como terrateniente y gran señor de sus tierras. No sueña con ser un ciudadano, en los términos modernos, pero sí con obtener tierras y ser un hacendado. Para esto, en el contexto del Sertón mineiro, antes deberá convertirse en un criminal. Esta característica contradictoria propia del contexto del bandolerismo es denominada por Antonio Cândido (2004) el ser atrofiado: "Nesse mundo em que as condutas são reversíveis, não se divisa o bandido e o não-bandido: -O mesmo homem pode ser hoje soldado e amanhã jagunço, ou o contrário" (Cândido, 2004, p.112).

Si Wilhelm soñaba con ser actor, Riobaldo deberá interpretar diferentes papeles dentro de un grupo criminal al que se une. "A vida da gente vai em erros, como um relato sem pés nem cabeça, por falta de sisudez e alegria. Vida devia de ser como sala do teatro, cada um inteiro fazendo com forte gosto seu papel, desempenho" (Rosa. G,1986, p. 251).

La ambigüedad será la característica de este personaje, y por eso lo de atrofiado. Una ambigüedad que le impide tener una personalidad definida fuerte. Nada es definido, todo es una permanente interrogación. "Vivendo, se aprende; mas o que se aprende, mais, é só fazer outras maiores perguntas" (Ibíd., p. 589).

Ninguna de las características de su personalidad se va a desarrollar por completo, pero no será un ser frustrado, su ontología estará marcada por la contradicción.

Eu careço de que o bom seja bom e o ruim ruim, que dum lado esteja o preto e do outro o branco, que o feio fique bem apartado do bonito e a alegria longe da tristeza! [...] Este mundo é muito misturado . (Rosa. G, 1986, p. 308)

Riobaldo solo conseguirá un éxito parcial en uno de los papeles que intenta interpretar cuando hace un pacto con el demonio y logra llegar al comando del grupo de bandoleros.

El jagunço es un tipo social históricamente específico. Encarna las formas más plenas de la contradicción, porque el propio sertón es contradictorio. Sertón es un espacio de intersección de modos de producción diferentes, lo premoderno y lo moderno conviven, no necesariamente de forma armónica, y por lo tanto ser bandido no es una deformación. Ni tampoco convertirse en 
bandido es algo que está fuera de la lógica de este lugar. Todo es provisorio, aunque los valores sociales dominantes son conservadores. Dice Cândido:

\begin{abstract}
no mundo-sertão não significa necessariamente deformação, pois este mundo, traz imanentes certas formas de comportamento que no jagunço são levadas a termo e se tornam coerentes. 0 jagunço atualiza, dá vida a essas possibilidades atrofiadas do ser, porque o sertão assim o exige. (Cândido, 2004, p.114).
\end{abstract}

El ser atrofiado significa que ninguna de las tendencias de la personalidad que podrían desarrollarse se terminan desarrollando completamente. Es la vivencia de la modernidad brasileña, una modernidad subdesarrollada con respecto al centro del mundo capitalista. E. Hobsbawm, en Bandidos (1976), dice que la ambigüedad caracteriza la personalidad de los integrantes de grupos de delincuentes y destaca que esto se debe, en parte, a que allí, todo es mucho más provisorio y perenne, porque están al margen del sistema, todo puede cambiar en cualquier momento. El bandido debe aprender a comportarse de formas muy diferentes $\mathrm{y}$ a veces contradictorias.

Riobaldo en esta caracterización de ser atrofiado tendrá un lado no ejemplar, y un lado ejemplar. Para conformar literariamente el lado no ejemplar del personaje, Guimarães crea un pícaro. Un ser trepador, inescrupuloso, un valentón, asesino y violento, pero también un buscavidas bienhumorado que se acerca al pícaro.

Com a dureza de querer, que espremi de minha sustância vexada, fui sendo outro - eu mesmo senti: eu Riobaldo, jagunço, homem de matar e morrer com a minha valentia. Riobaldo, homem, eu, sem pai, sem mãe, sem apego nenhum, sem pertencências (Rosa. G, 1986, p.155).

Al rescatar el habla popular del sertón, el personaje adquiere una ética picaresca, que mezcla estrategias de supervivencia y sabiduría popular. Esta ética incorpora un cierto pragmatismo: " $O$ correr da vida embrulha tudo, a vida é assim: esquenta e esfria, aperta e daí afrouxa, sossega e depois desinquieta. 0 que ela quer da gente é coragem. ” (Rosa, G, 1986, p. 449). “Obedecer é mais fácil do que entender" (Rosa. G, 1986, p. 463).

Dentro del grupo, los comportamientos se adaptan a la situación. En algunos momentos es necesario el coraje, en otros hay que obedecer: "Eu quase que nada não sei. Mas desconfio de muita coisa” (Rosa. G, 1986, p. 15).

El conocimiento no es algo sistemático y sí intuitivo.

La novela picaresca del Renacimiento utiliza mucho la crítica social, usa el humor, y se vale de los defectos más que de las virtudes, no siendo por eso ejemplar como la novela de aprendizaje.

Apenas comienza su proceso de aprendizaje, Riobaldo comprende que las reglas del éxito no pasan por la educación formal. En su infancia, estudia y hasta llega 
a enseñar a leer a algunos de sus compañeros bandoleros, pero las letras son un conocimiento secundario. El "hacerse hombre" es el objetivo de su formación y así debe adecuarse a las reglas del sertón. La lógica que guiará sus acciones será 1) la violencia y 2) lo sobrenatural, además de aceptar 3) la existencia de una especie de simbiosis con la naturaleza, en la que esta funciona como una especie de maestra de los sertanejos.

1) La ley del sertón es la ley bruta del más fuerte, por la violencia se impone el bandido y no hay casi espacio para la razón: "Viver é muito perigoso: sempre acaba em morte" (Rosa. G,1986, p 63).

2) Posibles pactos con el demonio o intervenciones divinas. Ambas tienen una importancia fundamental en la novela y en la formación de Riobaldo. Principalmente el pacto con el demonio. Este elemento que algunos pensaron que tenía algún punto de contacto con el Fausto de Goethe o el de Thomas Mann, tiene posiblemente más que ver con la cosmovisión medieval sertaneja. El pacto con el demonio se va a convertir en un hecho fundamental en el proceso de formación del jefe de los jagunços. El rito iniciático le permitirá a Riobaldo obtener la energía suficiente para realizar acciones reprobables, consideradas malvadas, pero que son necesarias para conseguir su objetivo. Dios y el demonio son fuerzas fundamentales en el espíritu de los personajes del sertón: “Quem-sabe, a gente criatura ainda tão ruim, tão, que Deus só pode às vezes manobrar com os homens é mandando por intermédio do diá?” (Rosa. G, 1986, p. 50)

3) La tierra y todos los elementos de la naturaleza funcionan como una especie de madre que da vida y enseña a vivir. La tierra, la región y sus habitantes son como un único ser. Hay una simbiosis entre la naturaleza y los habitantes de la región: una especie de cosmovisión indígena irrumpe en la historia, y la lógica de la tierra tiene sentido, como una lógica diferente de la razón humana, inclusive superior a esta: “Sertão: é dentro da gente” (Rosa. G, 1986, p. 436).

En síntesis, Gran Sertón: Veredas es una novela de aprendizaje en su versión brasileña, que incorpora otros elementos estéticos, pero resiste a su clasificación de aprendizaje porque insiste en la escuela de la vida como, el cumplimiento de ciertas etapas que moldean una ética.

Para conformar el lado ejemplar de Riobaldo, Guimarães Rosa crea la figura de un paladín medieval. El paladín es un caballero, hombre de armas en la Edad Media que, valeroso, se distingue por sus hazañas. Generalmente defiende una causa justa. Es un justiciero y tiene códigos éticos propios relacionados al honor y a la gloria militar.

Para incorporar un paladín, el relato usará algunos elementos de la novela de caballería. De esta forma encontramos en la novela:

a) una narración que presenta una estructura abierta de carácter episódico, algunas aventuras se prolongan indefinidamente. Son las aventuras de ban- 
das de criminales, todas integradas por Ribaldo hasta que llega a ser el jefe.

b) amplificaciones, exageraciones y una Geografía totalmente fantástica

c) una acción que tiene un valor moral y ético superior, la búsqueda de honra, valor, aventura a través de diferentes desafíos.

d) la idealización del amor del caballero por su dama (Otacilia) y algunas amantes (Nhoriná) y relaciones paralelas (en la novela tenemos el caso del amor de Riobaldo por Diadorim, que es mujer, pero toma la apariencia de un hombre para poder participar del grupo).

e) violencia glorificada, justificada por un fin ético.

Guimarães Rosa puede representar así estos restos del pasado colonial brasileño, utilizando en la novela elementos arcaicos de la sociedad sertaneja. La trama, al incorporar elementos de caballería, deja de ser una mera historia de villanos pícaros despreciables, para asumir cierto heroísmo encarnado en un paladín. Los ideales del paladín, que son parte del imaginario de la novela de caballería, le van a permitir al jagunço superar la esfera de la criminalidad. Los paladines se rigen por un código de ética corporativo y estricto cuya norma fundamental es la lealtad con los compañeros y con el líder (Cândido, 2006, p.120).

El paladín lucha contra injusticias. La violencia justiciera se materializa principalmente contra grandes terratenientes como Timóteo Regilmidiano da Silva, o Zabudo, e seô Habão. De a poco, Riobaldo y su banda adquieren un sentido de justicia contra la máquina económica que controla la región, y, por momentos se siente que el ejercicio de la violencia está justificado, porque hay un fin bueno en sí mismo, una ética comunitaria. La contradicción entre lo arcaico medieval y lo justiciero está representada en esta esfera del paladín Riobaldo.

Paladín y bandido pícaro serán los dos polos entre los que transitará el personaje, que no terminará de desarrollar ninguno de los dos, puesto que cuando llega a la jefatura de la banda abandona definitivamente el grupo ante la muerte de su amado Diadorim.

Una vez más la contradicción irrumpe en la trama puesto que el amor, que se contrapone al mundo violento de los bandidos y que salva al héroe de la locura durante casi toda la trama, mostrará su lado trágico y descontrolado, profundizando la ambigüedad del personaje. Como dijimos, por un lado, el amor salva de la locura y del odio: "Só se pode viver perto de outro, e conhecer outra pessoa, sem perigo de ódio, se a gente tem amor. Qualquer amor já é um pouquinho de saúde, um descanso na loucura" (Rosa. G,1986, p. 440).

Pero en sus experiencias amorosas Riobaldo también experimentará la ambigüedad. A diferencia de Wilhelm Meister, que lucha por un gran amor y que finalmente logra una cierta madurez cuando es padre y debe cuidar a su hijo, Riobaldo tendrá una vida amorosa oscilante. El paladín tendrá una doncella amada Otacília, dama inspiradora que terminará siendo su esposa. Pero sabemos que su gran amor será su compañero Diadorim, joven del cual finalmente sabrá que es una mujer disfrazada de hombre, símbolo de todas las ambigüedades que 
definen a la novela y al propio proceso formativo del héroe: villano. También se enamora de una prostituta Nhoriná, símbolo de la seducción y la voluptuosidad. Riobaldo termina en un casamiento tradicional completando así un desarrollo emocional tumultuoso, atrofiado en algún sentido (Diadorim), pero que finalmente se concreta en una de sus formas, el casamiento tradicional con Otacília, que tranquiliza las fuertes emociones del corazón.

\section{El narrador que sutura heridas}

La novela tiene un narrador tradicional, tal como fue descrito por Walter Benjamin, que a través de la oralidad cuenta historias de un pasado aventurero de su vida en el sertón a través de las cuales adquiere un saber. Sin embargo, su platea no es la comunidad rural sertaneja y sí un interlocutor extraño. Alguien que viene de la ciudad, con una formación académica, es doctor, y tiene una cultura y una discursividad diferentes de la del sertón. Esta conformación de personajes contrapuestos por su historia y por su proceso de formación va a dar lugar a un discurso narrativo en el que dos paradigmas se conjugan: campo y ciudad, arcaico y moderno, sertón y grandes centros urbanos. La tradición oral rica y creativa del universo sertanejo y el relato épico se chocan con la estructura lógica de la novela burguesa en su versión picaresca, de aprendizaje, o de vanguardia. Estos choques o conjugaciones producen una arquitectura narrativa peculiar que tiende siempre al esclarecimiento. Parte del misterio de los oscuros mitos rurales y de las todopoderosas fuerzas metafísicas de Dios y el diablo e intenta acercarse a un conocimiento del mundo a través de la experiencia, no del arte, como en Goethe, y sí de una travesía por una región atrasada que ve la modernización como algo inminente, ajeno y problemático. Davi Arrigucci en su excelente ensayo "O mundo misturado" (1994) ya destacaba esta característica de la novela de Guimarães Rosa:

\footnotetext{
O problema que ora se coloca é, pois, compreender como se dá a sutura entre as formas que vêm da tradição dos narradores anônimos da épica oral sertaneja [...] e o nascimento de uma forma da sociedade urbana moderna - o romance - que renasce em pleno interior do Brasil, de dentro do arcaico que é o mar do sertão, como se de repente, se refizesse em nosso meio a história de um gênero decisivo para a modernidade, brotando de um outro tempo. A questão é, pois, ainda entender a forma mesclada de um livro em que diversas temporalidades narrativas se misturam, correspondendo ao mundo misturado que é a nossa própria realidade (Arrigucci, 1994, p. 24).
}

Sutura es la palabra que usa Arrigucci para describir el proceso narrativo en Gran Sertón: Veredas. Guimarães Rosa, como médico, conocía los procedimientos de sutura, y como médico, representante de la ciencia en un ambiente tan arcaico, conocía estas otras heridas, sabía en carne propia que pensar el sertón en términos de modernidad implicaba una operación dolorosa entre partes rasgadas por una realidad cruel. El texto entonces es un texto difícil, plagado de costuras de este tipo, suturas que unen partes desgarradas. Veamos a continuación algunos ejemplos de esta sutura: 
a) Riobaldo, el ex jaguço, tiene como narrador un estilo sofisticado que lo lleva a transitar por especulaciones típicas del conocimiento letrado. Se cuestiona el sentido de la vida, la propia existencia, lo que lo acerca al narrador típico del romance burgués. "O senhor ache e não ache. Tudo é e não é" (Rosa. G, 1985, p.10)

b) En el relato lo mítico es y no es. Al final de la novela Riobaldo deja abierta la duda: “¿el Diablo existe o no?" "Amável o senhor me ouviu, minha idéia confirmou: que o Diabo não existe. Pois não?” (Ibíd., p. 875).

La presencia de Dios y principalmente del Diablo determinan el destino del personaje en gran parte del relato. Los mitos parecen darle sentido a parte de su vida. La relación de amor con Diadorim está marcada por una especie de destino marcado desde la infancia en que se conocen pescando en el río. Por eso, es la única escena infantil que aparece y la muerte trágica del gran amor es la señal de que todo ese proceso acabó. El destino marcado por fuerzas superiores se contrapone a la búsqueda del propio camino característico de la individualidad urbana. Destino marcado y búsqueda individual se contraponen en una sutura difícil.

Hay momentos en que el mundo encantado se vuelve una pesadilla y es mejor despertarse: “Tem horas em que penso que a gente carecia, de repente, de acordar de alguma espécie de encanto" (Ibíd., p. 111).

El ideal moderno del hombre dueño de su destino y de la travesía que nunca acaba hasta el último instante se interpone en la sutura dura del relato: "O senhor é um homem soberano, circunspecto. Amigos somos. Nonada. O diabo não há! É o que eu digo, se for... Existe é homem humano. Travessia” (Ibíd., 1985, p .875).

c)Sin embargo podemos divisar una dirección en esta tarea quirúrgica del texto. El narrador camina hacia un esclarecimiento guiado por la luz de la razón que, como dice Kant, nos saca de la oscuridad de la superstición y del mundo de la violencia. En un esquema parecido al que Adorno y Horkheimer señalan en Dialéctica de la Ilustración, en el que se le saca peso al mundo encantado e irracional de los dioses: "Pontaria, o senhor concorde, é um talento todo, na idéia" (Ibíd., p. 139).

El trayecto del narrador personaje es individual. Su formación también. Pasa del bandidaje a ser un propietario de tierras casado y pacífico. La barbarie da lugar a una cierta civilización. Sin embargo, Riobaldo es un héroe problemático. Busca la modernidad en un terreno arcaico. Y eso genera problemas. El resultado final es un discurso con suturas que no se agota. El símbolo final de la novela es el de la NONADA, la eternidad. Sugiere que Brasil se define en este continuum problemático muy difícil de ser roto.

Podemos concluir diciendo que, en este mundo mezclado en el que se mueve el narrador y que nos legó un texto con dimensión trágica, motivos y procedimientos épicos, tradición literaria popular y erudita, se amalgaman en una sutura difícil pero altamente consciente de los límites de la situación histórica y cultural 
brasileña. Estos límites tienen que ver con el pasado colonial que resultó en una sociedad atrasada, que mezcla elementos arcaicos tradicionales y conservadores con lógicas modernas que se chocan generando un discurso transculturado, como lo describió Ángel Rama (2008). Si pensamos en el discurso del narrador como producto de su proceso formativo, encontramos en él una gran consciencia de esta situación. Para Arrigucci, ya vimos que esta consciencia no pasa del plano individual. Para el crítico Willi Bolle, este esfuerzo de juntar dos discursos opuestos es el principal mensaje da la novela. Representaría en el nivel estético textual la pretensión de diálogo de clases. Las clases populares representadas por las tradiciones orales y algunas prácticas colectivas y las clases dominantes representadas por la estética de la novela moderna y la exaltación de la ciencia y la acumulación de bienes. Este diálogo mostraría una perspectiva positiva para el futuro del país que, sin embargo, debería pasar por una sutura muy dolorosa.

\section{El papel de la naturaleza. El Sertón}

La naturaleza cumple un papel central para los pobladores del sertón. Para Cândido la tierra, el sertón, las veredas son la fuente de vida de los habitantes de ese lugar que la ven como una especie de gran maestra.

Sertão é isto: o senhor empurra para trás, mas de repente ele volta a rodear o senhor dos lados. Sertão é quando menos se espera (Rosa. G, 1986, p. 403).

La tierra, el sertón, tiene vida propia y se manifiesta como si fuese un ser vivo. Ver a la tierra como un espíritu superior al ser humano es parte del animismo propio de la cosmovisión de los pueblos americanos, muy arraigada en las poblaciones tradicionales. El Sertão abre y cierra caminos con su rudeza. El hombre lo controla y así aprende a vivir, pero la tierra también tiene sus leyes que no pueden ser violadas.

O senhor escute meu coração, pegue no meu pulso. O senhor avista meus cabelos brancos...Viver-nãoé?-émuito perigoso. Porque ainda nãosesabe. Porque aprendera-viver é que é o viver, mesmo. 0 sertão me produz, depois me enguliu, depois me cuspiu do quente da boca... O senhor crê minha narração? (Rosa. G, 1986, p.841).

La violencia también proviene de la tierra indómita (Somos bárbaros porque la tierra nos hace así). Las formas de la naturaleza, al enseñar y determinar tanto al individuo, terminan por aparecer en la conformación de su personalidad, en su comportamiento y en las formas de expresarse. El habla popular se nutre de imágenes y metáforas sacadas de la naturaleza. Según Cândido, esta interiorización de la naturaleza es uno de los procesos fundamentales de formación de Riobaldo y del hombre sertanejo en general. Pero también la naturaleza "aprende" del hombre en un proceso simbiótico y dialéctico. Aparece en la novela la idea de la intervención humana en la naturaleza, que es una intervención anímica, no material. El caso más típico se da en la escena en que los bandoleros deben 
atravesar un gran desierto llamado Liso do Sussuarão, que será una vez intransitable y la segunda, pasable. La primera, cuando Riobaldo todavía es un miembro de la banda y están persiguiendo a un tal Hermógenes, no logran atravesarlo. En el segundo intento, luego del pacto con el demonio y con toda la energía positiva que sienten, logran atravesarlo. En este caso, el mundo físico parece aceptar los deseos humanos y se rinde a ellos. Este elemento animista es un componente arcaico que penetra el texto.

Aparte de la naturaleza como personaje tenemos el espacio del sertón como topos de la acción. Hay dos topos en la novela. Uno donde se mueve el jagunço pícaro este un espacio geográfico reconocible. El otro es un espacio mágico encantado y legendario donde perdemos totalmente las referencias, por donde se mueve el paladín. En el texto, lo reconocible y lo mágico se funden. El río São Francisco, por ejemplo, accidente físico y realidad mágica, curso de agua y Dios fluvial, rio que corta el sertón, que hiere en el sentido que vimos en el apartado anterior ("O São Francisco partiu minha vida em duas partes"), su función es dividir el mundo en dos lados diversos, marcados por el sentido simbólico. Dice Cândido:

\footnotetext{
Na margem direita, os fatos que marcam a primeira parte da vida do jagunço Riobaldo: - Margem do grande chefe justiceiro Joca Ramiro; do artimanhoso Zé Bebelo; da vida normal no Curralinho; da amizade reta (apesar da revelação na Guararavacã do Guaicuí) por Diadorim, mulher travestida em homem. $\mathrm{Na}$ esquerda, os acontecimentos que se sucedem ao assassinato de Joca Ramiro: - Margem da vingança e da dor, do terrível Hermógenes e seu reduto no alto Carinhanha; das tentações obscuras; das povoações fantasmais; do pacto com o diabo (Cândido, 2006, p.114).
}

El ser atrofiado del personaje principal circula por espacios de diferente tipo. Los dos márgenes del río que corta el Sertón también tienen un valor moral y educativo diferente para el héroe. Al comienzo de la historia en una canoa, Riobaldo y Diadorim, todavía niños, se conocen. Mientras navegan por el río tocan las dos orillas, uniendo los dos lados, suturando mundos diversos. La experiencia de la travesía resume el viaje formativo que el personaje emprenderá a lo largo del relato. Conociendo el sertón y sus dos lados y forjando así esa personalidad ambivalente y reversible. La naturaleza virgen como instancia formativa tiene un gran valor para el sertanejo que ve en ella su origen y también un mundo todavía no contaminado por la modernidad.

\section{La integración social del héroe}

Hay varios modelos sociales en juego en Gran Sertón: Veredas. Por un lado, la sociedad sertaneja, pautada por la violencia en la que las disputas son la norma y no la excepción. La naturaleza dicta sus ritmos como una maestra. Las leyes de la sociedad sertaneja se oponen a las leyes de la ciudad. La ciudad es un modelo de sociedad que el jagunço no entiende. Las leyes de la ciudad están prohibidas y 
son consideradas dañinas para los integrantes de la banda y para el sertón como un todo. La llegada del estado republicano es identificada con algo maligno para la mayoría de los bandoleros.

En las acciones de estos bandoleros aparece un desprecio por las leyes ciudadanas. Veamos por ejemplo la escena del juicio a Ze Bebelo. El gobierno del estado de Minas contrata un bandolero, Ze Bebelo, para luchar contra los irregulares e imponerles la ley. Zé bebelo es capturado y se le aplica un juicio en la Fazenda Sempre-Verde:

"O senhor veio querendo desnortear, desencaminhar os sertanejos de seu costume velho de lei..." - "Velhoé, o que já está de si desencaminhado. O velho valeu enquanto foi novo." - "O senhor não é do sertão. Não é da terra." - "Sou do fogo? Sou do ar? Da terraéé a minhoca - que galinha come e cata: esgaravata!" (Rosa. G., 1986, p. 243).

Fijémonos en la primera frase aparece el verbo desnortear. Cândido comenta que puede tener un doble sentido de confundir y de sacarles el Norte, la región de Minas donde actúan estos jagunços. Esta región tiene su propia ley y costumbre, que, según el narrador, debe ser respetada. Como ya dijimos, la ley parece emanar de la propia naturaleza (tierra, aire y fuego) y el hombre la debe conocer y respetar. Esta parece ser la ley fundamental del sertón. Las leyes de la ciudad "desnortean".

Sin embargo, hay un fuerte contraste entre la postura del narrador, Riobaldo ya viejo, que después de haber pasado por todos los años de aprendizaje tiene un nivel de conciencia diferente. Cândido menciona la presencia de dos tempos en el texto. El tempo del narrador y el de la narración. El narrador que pasó por el proceso de aprendizaje hace un balance. Recordemos que el relato consiste en un monólogo, pero hay un interlocutor, alguien que vino de la ciudad y que parece que tiene estudios, a quien se refiere en estos términos respetuosos: "inveja minha pura é de uns conforme o senhor, com toda leitura e suma doutoração" (Rosa. G,1986, p.14).

Vemos aquí que el viejo Riobaldo resalta el carácter de letrado de su interlocutor como algo a admirar, a envidiar y que, por lo tanto, es una falta en su formación.

En este embate entre el tempo del narrador y el de la narración tenemos una puesta en escena de un debate profundo sobre algunas características de la vida social brasileña. El hecho de estar en la periferia del mundo moderno occidental, con amplios sectores viviendo y teniendo que desarrollarse en contextos tradicionales, por un lado, y la presión de una modernidad global, por otro, encuentra un panorama complejo de contrastes.

En la sociedad del sertón reina la violencia y la desprotección. La ausencia del estado es visible. La religión y lo sobrenatural a veces ocupan ese lugar vacío. Dios y el Diablo dan la energía que el Estado y la sociedad urbana no llevan a lugares alejados: “Deus é paciência. O contrário é o diabo” (Rosa. G, 1986, p.18). 
Riobaldo necesita este pacto como una inyección de ánimo y energía para cumplir sus deseos. Todo lo relacionados al pacto con el demonio tiene características míticas, fantásticas. Cândido afirma:

O diabo surge então, na consciência de Riobaldo, como dispensador de poderes que se devem obter; e como encarnação das forças terríveis que cultiva e represa na alma, a fim de couraçá-la na dureza que permitirá realizar a tarefa em que malograram os outros chefes (Cândido, 2006, p.122).

La elección del Diablo y no de Dios, comenta Cândido, parece referirse a la naturaleza bruta del sertón que tiene cierta malicia y que exige un grado de maldad y violencia para sobrevivir. Pero también es posible hacer el bien gracias al poder dado por el diablo. Esta es una peculiaridad del jagunçismo. Encontramos aquí, según Cândido, una de las contradicciones fundamentales de la obra. Hacer el bien a través del mal:

O trato com o diabo aparece, nessa perspectiva, como um instrumento de transcendência da representação histórica em Guimarães Rosa: - Isto talvez possa ser considerado como um sinal a mais do seu jaguncismo peculiar, e nada mais faz que ajustar o ser à craveira que permite realizar a sua missão: fazer o bem através do mal, nutrindo com as operações de ódio um amor desesperado e imenso (Cândido, 2004, p.118).

Efectivamente, es a través del pacto diabólico que Riobaldo pasa de ser de un simple bandido a ser un paladín de la justicia y pasar de actuar solo cuidando del aspecto individual (egoísta) al colectivo al comandar el grupo. Y esta es una transformación fundamental en el camino de aprendizaje del sertanejo:

Bandido e não-bandido, portanto, é um ser ambivalente, que necessita revestirse de certos poderes para definir a sí mesmo. O pacto desempenha esta função na vida do narrador, cujo Eu, a partir desse momento, é de certo modo alienado em benefício do Nós, do grupo a que o indivíduo adere para ser livre no Sertão, e que ele consegue levar ao cumprimento da tarefa de aniquilar os traidores, os -Judas" (Cândido, 2006, p.129).

¿Hay reconciliación en esta historia de jagunços brasileños? Pensemos en el ya citado ensayo de Wlli Bolle sobre el diálogo de clases que es posible vislumbrar en la novela. Podemos pensar en una reconciliación parcial a través de este diálogo del personaje narrador, Riobaldo, con un visitante foráneo al que relata su vida. Este es una persona letrada a quien el narrador dice estimar. Pero crea un lenguaje propio para el relato que se opone al discurso académico convencional. Y, además, jamás le da la palabra, en un gesto que nos hace dudar sobre la estima que realmente le tiene. Sin embargo, esta reconciliación nos parece sospechosa o parcial y nos hace dudar de su existencia, tal como la entendía Bajtín o el joven Lukács, como el momento en que voluntariamente un individuo se integra a la sociedad para así desplegar toda su personalidad. Adorno (2003) propone un modelo en el que el narrador funciona como una especie de resumen 
de los fragmentos del texto. Para el Lukács maduro de la Estética 2, el Wilhelm Meister mostraba un improbable estado medio entre individuo y mundo. Una improbable reconciliación. Gran Sertón: Veredas refuerza estas contradicciones a nivel estético, que figuran una vida social también plagada de contradicciones que confirman el carácter realista de la obra.

\section{Conclusiones}

En Gran Sertón: Veredas podemos identificar algunos elementos de la novela de aprendizaje que figuran literariamente una sociedad periférica subdesarrollada como la brasileña. Utiliza un narrador-personaje que funciona como un héroe atrofiado, que oscila entre ser y no ser bandido, ser y no ser un paladín. El narrador concentra en sí una serie de características arcaicas, modernas, locales y universales que representan a nivel de la voz del relato la naturaleza contradictoria de la vida social brasileña producto de su pasado colonial y su presente de nación subdesarrollada. Un elemento tradicional y arcaico que contribuye a la conformación de este escenario atrofiado es la figuración de la naturaleza como maestra espiritual que mantiene una relación simbiótica con el hombre del sertón. El personaje protagonista tiene una actitud ambigua con respecto a la sociedad en la que vive. Cuando joven, rechaza los valores urbanos en nombre de una ética rural que en su caso incluye los códigos bandoleros. Cuando viejo, el personaje narrador rescata algunos valores de la ciudad como la educación formal, pero sin adherir efusivamente a los mismos, manteniendo con su interlocutor, un letrado de la urbe, una actitud de desconfianza. Podemos concluir diciendo que el relato de los años de aprendizaje de Rioblado el jagunço mineiro de Guimarães Rosa puede ser visto como un tipo particular de novela de aprendizaje que figura una vida social con profundas contradicciones como la brasileña. 


\section{Bibliografía}

" Adorno, T. (2003). Posição do narrador no romance contemporâneo. En: Notas de Literatura I (Trad. de J. de Almeida). San Pablo: 34 Letras.

" Arrigucci Jr., D. (1994). O mundo misturado: romance e experiência em Guimarães Rosa. Novos Estudos. 40, 7-49.

" Bajtín, M. (2011), Estética da Criação Verbal (Trad. de M. E. Galvão G. Pereira). San Pablo: Martins Fontes.

" Bastos, H. (2009). As artes da ameaça: um percurso de Vidas secas a Meu tio o lauaretê. Cultura crítica, 8, 46-51.

" Benjamin, W. (1972). Krisis des Romans. Zu Döblins Berlin Alexanderplatz. En: -, Gesammelte Werke. Vol. III (pp. 230-236). Frankfurt/M: Suhrkamp.

" Benjamin, W. (1985). Franz Kafka, A propósito do décimo aniversário de sua morte. En: Obra Escolhida (Trad. de S. P. Rouanet): Vol.1: Magia e Técnica, Arte e Política (pp. 137-164). San Pablo: ed. Brasiliense.

" Benjamin, W. (2009): Ensaios reunidos: Escritos sobre Goethe (Trad. de M. Krausz Bornebusch, I. Aron y S. Camargo). San Pablo: Editora 34.

"Bolle, W. (2004). Grandesertão.br: o romance de formação do Brasil. San Pablo: Duas Cidades/Ed. 34.

" Candido, A. (1979). "Literatura e subdesenvolvimento". En: Moreno, César Fernández (coord.). América Latina em sua Literatura (pp. 343-62) San Pablo: Perspectiva.

"Candido, A. (2002) "O homem dos avessos". En: Tese e Antítese. San Pablo: T. A. Queiroz,

"Candido, A. (2004). Vários escritos. San Pablo: Duas Cidades; Río de Janeiro: Ouro sobre Azul.

"Candido, A. (2006). A educação pela noite. Río de Janeiro: Ouro sobre Azul.

"Candido, A. (2009). Formação da literatura brasileira: momentos decisivos. San Pablo: Fapesp; Río de Janeiro: Ouro sobre Azul.

"Candido, A. (2011). Entrevista. Marília. Trans/Form/Ação, 34, 3-13.

" Dilthey, W. (1953). Vida y poesía (Trad. de W. Roces). México: FCE.

" Facó, R. (1976). Cangaceiros e fanáticos: gênese e lutas. Rio de Janeiro: Civilização Brasileira.

" Goethe, J. W. (2000). Los años de aprendizaje de Wilhelm Meister. (Trad. de M. Salmerón). Madrid: Cátedra.

" Hegel, G. W. F. (2007). Lecciones sobre la estética (Trad. de A. Brotons Muñoz). Madrid: Akal.

" Hobsbawn, E. (1976). Bandidos. (Trad. de D. Magalhães Garschagen). Rio de Janeiro: Forense-Universitária.

" Horkheimer, M y Adorno, T. (1988). Dialéctica del iluminismo (Trad. de H.A. Murena). Buenos Aires: Sudamericana

" Koval, M. (2015). Lukács y Los años de aprendizaje de Wilhelm Meister; Herramienta, $56(4), 141-150$. 
" Lorenz G. (1995). "Diálogo com Guimarães Rosa". En: João Guimarães Rosa. Ficção completa: Vol. I. (p. 35). Río de Janeiro: Nova Aguilar.

"Lukács, G. (1968). Goethe y su época, precedido de Minna von Barnheim (Trad. de M. Sacristán). Barcelona/México: Grijalbo.

"Lukács, G. (2009). A teoria do romance: um ensaio histórico-filosófico sobre as formas da grande épica. San Pablo: Duas Cidades; Editora 34.

" Lukács, G. (2011). Escritos de Moscú. Ed. de Miguel Vedda. (Trad. de M. Vedda y Martín Koval). Buenos Aires: Gorla.

" Marks, M.C (2018). "No meio da Travessia". Revista Literatura e Sociedade, 27, 131-145.

"Moretti, F. (1987). The way of the world: The Bildungsroman in European Culture. Londres: Verso.

"Rama, Á. (2008). Transculturación narrativa en América Latina. Buenos Aires: Ediciones El Andariego.

"Rosa, J. G. (1985). Grande sertão: veredas. Río de Janeiro: Nova Fronteira.

"Schwarz, R. (1983). Grande sertão: a fala estudos En: Coutinho, E. (Org.) Guimarães Rosa (pp.378-89). Río de Janeiro; Brasilia: Civilização Brasileira; Instituto Nacional do Livro. (Col. "Fortuna Crítica", v.6).

"Schwarz, R. (2012). Martinha versus Lucrécia: ensaios e entrevistas. San Pablo: Companhia das Letras. 